\title{
INFLUENCE OF FAMILY BACKGROUND ON STUDENTS' DROP OUT FROM SECONDARY SCHOOLS IN YAKURR LOCAL GOVERNMENT AREA.
}

EFFIONG, OJI EKPO AND EDET, MONDAY INAH

(Received 8, November 2019; Revision Accepted 18, December 2019)

\begin{abstract}
The study examined the influence of family background on students' dropout from secondary schools in Yakurr local government area of Cross River State. The study adopted the descriptive survey design and paired t-test and independent t-test were used in analyzing the data collected. The instrument for data collection was a structured questionnaire known as the family background and students' dropout questionnaire (FBSSDQ)made by the researcher. One hundred and fifty (150) students were randomly sampled from five (5) selected secondary schools from the study area. Fifty (50) students were used for trial testing outside the population of the study. Kuder Richardson 20 (KR20) reliability estimate was used to determine the reliability indices of the three sub variables as follows: family size $=0.78$, parents' attitude $=0.81$ and parents' socio-economic/educational status $=0.73$ respectively. The results showed students do drop out from schools and that this situation is attributed to certain factors such as family size, parents' attitude, parents' socio-economic status and educational background. It was recommended that parents should be fully educated on population size and education, there should be a massive education campaign to enlighten the parents and the general society on alternative ways of checking school dropout and the government should not shift the whole responsibility of financing education to parents since most of the parents are financially handicap and poor.
\end{abstract}

KEYWORDS: family size, parents' attitude, parents' socio-economic status, dropout.

WORD COUNT: 3349.

\section{INTRODUCTION:}

There is an overwhelming evidence of students dropping out from Secondary School in Nigeria. Whenever students drop out from school; it is a clear indication that the society as a whole and the educational institutions in particular are not providing for the welfare of all its students.

According to Foxworth (2000) when schools work together with families to support learning, children tend to succeed not just in school, but throughout life. In fact, the most accurate predictor of a student's achievement in School is not income or social status, but the extent to which that students' family is able to create a home environment that encourages learning, express high (but not unrealistic) expectation for their children's achievement and future careers and become involved in their children's education at schools and in the community.

"A Dropout" according to the Oxford Advanced dictionary is anyone that abandons a course of study. It is someone who has left school or

Effiong, Oji Ekpo, Department of Integrated Science

Edet, Monday Inah, Department of Physics Cross River State College of Education Akamkpa. 
college before they have finished their studies.

The Encyclopedia America defines dropout as a person who leaves school before completing a course of study. In relation to the study, it means those who were not able to finish training and obtain certificate. This usually shows some elements of weakness, lack of confidence on one's goals.

The case of home background on the rate of dropouts of Secondary Schools students is seen in different ways. School dropout in its simplest meaning is the untimely withdrawal from school. These students who withdraw from school permanently end up not obtaining any certificate of graduation. The issue of school dropout is a global problem confronting the education industry not only in Nigeria but the world in general [Aslam (2004), De Cost (2005); and Morris (2014)].

The issue of school dropout in Nigeria has been with us for a very long time. Aslam (2004) noted that dropout is one of the most serious problems that have continued to bedevil our educational system since independence in 1960 from the colonial administration.

Aslam (2004) contended that after some people who received this formal education were offered some places in government employment, as one would expect, the number of people who wanted to go to school was now high, but the constraint was that the number of students to be admitted annually depend largely on the number of prospective places in various government department, which would be opened to successful students. And so there was a tendency for low performance not to have a place.

Consequently, the students' rate of dropout was so high and many of those who completed their course found themselves having to specialize in areas which did not appeal to them. Worst still, the staff were faced with the task of having to allocate students to professions, which interest was not of their decision and dropping out was the answer.

Another historical review of dropout was in curriculum arrangement of Plato academy. In remarking on the Plato's system, Kell (2001) described the system as being carefully planned to educate the "men of gold" to think, choose and rule, while training the "men of bronze" to accept the judgment of their leaders and obey them. In this context, the "men of gold" were those who could advance their education, while the "men of bronze" were the dropout. The intellectuals were supposed to rule, judge and dictate for the dropout, who were supposed to be obedient to them, work for them and allow them to their judgment.

According to Estevao and Alvares (2014) school dropout rate has been identified as a major wastage factor in the educational system of the Nation. At any rate, those who stay away between the limits are worth mentioning too. Although some of the students do not complete their years of studies in Secondary School Six years expected, after their usual enrolment, some of them attend other schools. Those students who initially enrolled, almost a percentage will not have earned a higher certificate. This is as a result of parental unawareness and lack of potentiality, system of farming adopted by parents which cannot meet up the academic requirements, size of the family and broken homes. A cross examination has shown that majority of the students don't even know their future ambition and as soon as they come out from primary school, their parents seem to push them into Secondary education level. (Shannon and Bylsma, 2006). This poses a great problem as the children soon drop out of school.

The national policy on education(FGN 2014) states that it is the duty of any responsible government to provide education at different levels to its citizens. Nevertheless, not all educational policies tend to provide alternative for the various scholars at their own level of education.

Runberger (2013), observed that considering the number of students that are admitted into Secondary Schools each year, one would expect that the number to be turned out at the end of the year's course would be about the same number admitted. But this is not the situation, as a much lesser number than the original number at the end of their courses drops out. It therefore means that certain factors such as socio-economic status of parents, parental attitude towards their children, educational status of parents, occupations of the parents, financial constraints contribute to the rate of dropout of Secondary School students. It is on this premise that this study seeks to address the influence of home background on the rate of dropout of Secondary School students.

\section{PURPOSE OF THE STUDY}

Since the problem of dropping out of Secondary School students is a controversy in the Country, the primary objective of this study is to find out how home background influences the rate of drop out from school. 


\section{SIGNIFICANCE OF THE STUDY}

The study will help the government to find alternative ways of engaging the rate of dropout and therefore make them relevant and useful citizens.

\section{RESEARCH QUESTIONS}

The following research questions are posed for the research work:

i. Does the size of the family have any significant influence on students' rate of dropout?

ii. Does parents attitude towards their children affects the rate of dropout?

iii. Do children from higher socio-economic class differ from those from the lower class in the rate of dropout of students?

iv. Does educational status of parents affects the rate of dropout of students?

\section{RESEARCH HYPOTHESIS}

The following hypothesis were formulated for the study at 0.05 level of significance.

1. There is no significant influence of family size on students drop out from school
2. There is no significant influence of parents' attitude on students' dropout from school 3. There is no significant influence of parents socio-economic status on students dropout from school

4. There is no significant influence of parents' educational background on students' dropout from school.

\section{METHODOLOGY}

The research adopted a survey design. A survey design is an instrument or tool for consistently implementing a scientific protocol for obtaining data from respondents. It is important to this research because it concerns only on idea and defines the scope to consider.

The population consists of all the approved public and comparable senior secondary schools in Yakurr Local Government Area. The random sampling technique was used to sample one hundred and fifty (150) students from five (5) secondary schools selected from the list of all approved secondary schools in the study area. The students were selected through random sampling, in that circumstance, every student had the opportunity of being selected.

The selected secondary schools in the area are as shown below:

\begin{tabular}{|l|l|l|}
\hline S/NO & NAMES OF SELECTED SECONDARY SCHOOL & $\begin{array}{l}\text { NUMBER OF STUDENTS } \\
\text { SAMPLED }\end{array}$ \\
\hline 1. & Community Secondary School, Nko & 30 \\
\hline 2. & Government Secondary School, Agoi Ekpo & 30 \\
\hline 3. & Community Secondary School, Assiga & 30 \\
\hline 4. & Community Secondary school, Idomi & 30 \\
\hline 5. & Ntinton Secondary School, Ekori & 30 \\
\hline & TOTAL & 150 \\
\hline
\end{tabular}

The major instrument used for the collection of data was the family background and students' school dropout questionnaire (FBSSDQ) designed by the researcher. The instrument was divided into two sections, sections $A$ and $B$. section A solicits for demographic data while section $B$ answers the questions proper. There were twenty (20) questions constructed for the respondent to tick his or her opinion. The questions were on a "Yes or No" basis. The instrument was given to two experts in test and measurement. The reduction of the instrument to twenty (20) questions ascertained the face and content validity of the instrument. Fifty (50) students were used for trial testing outside the sampled area. Kuder Richardson 20 (KR20) reliability estimate was used to determine the reliability indices of the three (3) sub variables as follows: family size $=0.78$, parents' attitude $=$ 0.81 , parents' socio-economic and educational status $=0.73$ respectively.

The researcher made personal visitation to the selected schools for the exercise. The principals and teachers of the selected schools were of great assistance. They properly educated the students on the mode of completion and so all the questionnaires distributed were retrieved successfully. The data collected were analyzed using paired t-test and correlated t-test.

\section{RESULTS AND DISCUSSIONS}

The result of the study was presented hypothesis by hypothesis as follows: 
Null hypothesis one: Family size and students' dropout from school.

The $\mathrm{Ho}_{1}$ was tested using paired t-test at 0.05

Table I: Summary data of pair t-test at $\mathbf{0 . 0 5}$ level of significant for family size and students' dropout. level of significant as shown in

\begin{tabular}{|l|l|c|l|l|l|l|}
\hline Variable & $\mathbf{N}$ & $\overline{\boldsymbol{X}}$ & $\mathbf{S D}$ & $\mathbf{D f}$ & $\mathbf{t}_{\text {cal }}$ & $\mathbf{t}_{\text {critical }}$ \\
\hline Family size & 150 & 13.43 & 2.16 & & & \\
\hline Students' dropout & 150 & 60.32 & 18.00 & 149 & 5.38 & 1.96 \\
\hline
\end{tabular}

*Significant at .05

From table I, Calculated t-value (5.38) is greater than critical value (1.96) at 149 degree of freedom and .05 level of significant for the twotailed test. The hypothesis of no significant influence is thus rejected. The result is there is significant influence of family size on students' dropout.

Null hypothesis two: Parents attitude and students' dropout

To test $\mathrm{Ho}_{2}$ correlated t-test was used as shown in table II below.

Table II: Summary data of correlated t-test at 0.05 level of significance parents' attitude and students' dropout.

\begin{tabular}{|l|l|c|l|l|l|l|}
\hline Variable & $\mathbf{N}$ & $\overline{\boldsymbol{X}}$ & $\mathbf{S D}$ & $\mathbf{D f}$ & $\mathbf{t}_{\text {cal }}$ & $\mathbf{t}_{\text {critical }}$ \\
\cline { 1 - 4 } Parents' attitude & 150 & 28.95 & 7.52 & 149 & 3.70 & 1.96 \\
\cline { 1 - 4 } Students' dropout & 150 & 60.52 & 18.00 & & & \\
\hline
\end{tabular}

*Significant at .05 alpha levels

Table II, Indicated that the Calculated t-value (3.70) is greater than critical value (1.96) at degree of freedom 149 and 0.05 level of significant for two tailed test. Based on this, the null hypothesis that stated that Parents' attitude does not significantly influence students' dropout is rejected. This implies that the influence is statistically significant.

Null hypothesis three: Parents' socio-economic and educational status does not significantly affect students' dropout from school. To test $\mathrm{Ho}_{3}$ correlated t-test was used as shown in table III.

Table III: Summary data for correlated t test at $\mathbf{0 . 0 5}$ level of significant for parents' socioeconomic and educational status and students' dropout from school.

\begin{tabular}{|l|l|c|l|l|l|l|}
\hline Variable & $\mathbf{N}$ & $\overline{\boldsymbol{X}}$ & $\mathbf{S D}$ & $\mathbf{D f}$ & $\mathbf{t}_{\text {cal }}$ & $\mathbf{t}_{\text {critical }}$ \\
\hline $\begin{array}{l}\text { Parents'socio- } \\
\text { economic/educational status }\end{array}$ & 150 & 30.35 & 10.26 & 149 & 5.60 & 1.96 \\
\hline Students' dropout & 150 & 60.02 & 18.00 & & & \\
\hline
\end{tabular}

*Significant at .05 alpha levels

Table III, showed the computed t-value (8.60) at 0.05 level of significance and 149 degree of freedom for the two tailed test. Therefore the null

\section{DISCUSSION OF RESULTS}

It was confirmed through the researcher that student do drop out from schools and that this situation is attributed to certain factors such as family size, parents' attitude, parents' socioeconomic status and educational background. Davis (2010) observed that family size was a hypothesis is rejected. Parents' socio economic and educational status statistically influence rate of students' dropout from school.

cause of drop out as a happy life depends on a suitable family size.

Beckmerger and Rusell (2018) stated that the size of the family often have part to play in the educational influence of children and the rate of dropout from schools. This is in view of the fact that large families are always hard to maintain, and in view of the present economic recession, 
only the rich can afford to adequately finance their families both education and otherwise. On the other hand, rowdiness of large families does not create a convenient atmosphere for learning at home while in smaller families there is always security and tranquility which enhances convenience for learning. So, large families result to increase in the number of school dropout as most families will not be able to meet or cater for the financial demands of the school.

On parental attitude and dropout of students from schools, the findings are in agreement with Uche (2010) who argued that parental attitude is a likely cause of students' dropout since parental attitude is strictly the decision of parents on how their children should be brought up whether under intensely free or relaxed atmosphere.

On Socio-economic/educational status and dropout of students from schools, the findings agree to the findings of Uche (2010) who agreed that some parents cannot provide three square meals for their children on daily basis, let alone buy text books. Edem (2011) in his study of child development maintained that when educational needs of the children are not adequately met, dropout occurs. Children from poor families find it difficult to cope effectively with their education. Certain textbooks maybe required for use in schools, but in a situation where these children cannot afford such textbooks which will help them and depend wholly on notes, they will hardly feel fine. Moreover, most of these children trek to school every day and may miss one or two subjects due to lateness. Where their parents cannot even afford to pay their school fees, they will be forced to leave the school, so, the rate of dropout will be the result of financial constraints of their parents. Davies (2010) says societies all over the world can be stratified into three major classes viz; lower, middle and upper classes by socio-economic status. He believes that, the social class which a parent belongs affects the educational or influences the educational development and the rate of dropout of their children.

In a similar development, Ibrahim et al (2017) in a regression analysis of parents and family life of children, discovered a significant difference between educational background of both the father and mother of high academic achievement and low academic achievement of some group of boys, $81 \%$ of the parents of the high achieving group had a college of education graduate degree, where $69 \%$ of the parents of the low achievement group especially the mothers had educational qualification below the college level.
The work of Inuwa (2014) 'Does home and school factors predicts students' dropout in Sokoto' revealed that children from literate home or students whose parents attained average academic achievement had significantly, better academic success than those from non-literate parents. He therefore concluded from his study that, parents' education is related to children's academic performance and the rate of dropout.

Accordingly, a literate parent who knows the value of education, will teach their children how to count and know the names of certain things before going to school so as to protect overwhelming issue of the rate of dropout from school Generally, the research has revealed that the rate of dropout is consequent of economic factors. Runberger, (2011).

\section{SUMMARY AND CONCLUSION}

This study was undertaken to find out the influence of family background on students' dropout from schools.

Based on the findings, the following conclusions were made:

i. Family size affects students' dropout from schools.

ii. Parents' attitude influence students' dropout from school.

iii. Parents' socio-economic and educational status influence students' dropout from schools.

\section{RECOMMENDATIONS}

To control the influence of home background and the rate of students' dropout from school, the following recommendations were made.

* Parents should be fully educated on population size and education.

* There should be a massive education campaign to enlighten the parents and the general society on alternative ways of checking school dropout.

*The new National policy Education should be implemented to take care of care rate of dropout.

*The government should not shift the whole responsibility of financing education to parents since most of the parents are handicap and poor.

*The training scheme for teachers should be intensified to meet the high demand of the Secondary schools' needs.

*Scholarship scheme should be introduced at all levels to alleviate the sufferings of students in institutions of learning.

${ }^{*}$ Responsible institution should step up efforts in providing permanent and lasting solutions to educational problems in the State with particular reference to the problem of dropout. 


\section{REFERENCES}

Aslam, F., 2004. Attitudes and Practices of post graduate medical trainees: Helping students to finish school. https://www.ncbi.nlm.nih.gov>pub

Beckmerger, J. J and Russell, L. T., 2018. Family structure and family management practices: Associations with positive aspects of youth well-being. https://journals.sagepub.com>abs

Davies D. R., 2010. Socio-economic status as factors in school dropout: An analysis of data in Africa.

Davies, D. R., 2010. Socio-economic status and its relationship to educational resources. https://rdw.rowan.edu>cgi

De cost P. L. 2005. High school dropout enrolment and graduation rate in California. Californian research bureau. Californian state library.

Edem, E., 2011. Child development and maintenance.

Edem, E and Udoh A. O., 2011. Human resource development and the productivity of the civil service of Cross River State. African Research Review - African Journals online vol5No1 2011. https://www.researchgate.net>2341

Estevao, P and Alvares M., 2014. What do we mean by dropout from school? www.coursehero.com

Foxworth, A. M., 2000. Bridging the Gap between schools and families: A family friendly approach. https://www.idra.org>resource-center>
Ibrahim, M; AbuBakar, $\mathrm{N}$ and Mamat, I., 2017. Influence of parental education on academic performance of secondary school students in Kuala. International journal of academic research in Business and Social sciences, 2017, vol7:No8.

Inuwa, A. M., 2014. Does home and school factors predicts students dropout in Sokoto? https://www.ijern.com>iournal.

Kell, M., 2001. Fiscal vulnerability and financial crisis in emerging market economies. www.researchgate.net

Morris, J., 2014. Attendance rates among socioeconomic status subgroups. www.nwmissouri.edu>library

National Policy on Education NPE 2008. Implementing Educational policies for national education progress.

Oxford Advanced Learners Dictionary 2011 edition.

Runberger, R. W., 2011. Dropping out: why students drop out of high school and what can be done about it. Cambridge, mass: Harvard University, press.

Runberger, R. W., 2013. overty and High school dropouts: The impact of family and community poverty on high school dropouts. The SES indicatorS (1), 3-6.

Shannon, G. S., 2006. Helping students finish school: Why students dropout and how to help them graduate. eric.ed.gov

Uche, N. J., 2010. Relationships among peer pressure, time management and academic performance in school adolescents in Delta state, Nigeria. University of Nigeria, Nsukka. 